\title{
Matrix Metalloproteinase-Sensitive Thermogelling Polymer For Bioresponsive Local Drug Delivery
}

\author{
Vivek Kumar Garripelli ${ }^{1}$, Jin-Ki Kim² ${ }^{2}$, Sejin Son ${ }^{3}$, Won Jong Kim ${ }^{3}$, Michael A. Repka ${ }^{1,4}$, and \\ Seongbong Jo ${ }^{1}$ \\ ${ }^{1}$ Department of Pharmaceutics, School of Pharmacy, The University of Mississippi, University, \\ MS-38677, USA. \\ ${ }^{2}$ Division of Molecular Pharmaceutics, Eshelman School of Pharmacy, The University of North \\ Carolina at Chapel Hill, Chapel Hill, NC 27599, USA. \\ ${ }^{3}$ Department of Chemistry, BK21 program, Polymer Research Institute, Pohang University of \\ Science and Technology, San 31, Hyoja-dong, Pohang 790-784, Korea. \\ ${ }^{4}$ National Center for Natural Products Research, The University of Mississippi, University, \\ MS-38677, USA.
}

\begin{abstract}
Development of a successful bioresponsive drug delivery system requires exquisite engineering of materials so that they are able to respond to the signals stemming from the physiological environment. In this study, we proposed a new Pluronic ${ }^{\circledR}$ based thermogelling system containing matrix metalloproteinase-2 (MMP2) responsive peptide sequences. A novel thermosensitive multiblock copolymer comprising an MMP2-labile octapeptide (Gly-Pro-Val-Gly-Leu-Ile-GlyLys) was synthesized from Pluronic ${ }^{\circledR}$ triblock copolymer. The polymer was designed to form thermogel at body temperature and degrade in presence of MMP overexpressed in the tumor. The synthesized polymer was a multiblock copolymer with $\sim 2.5$ units of Pluronic ${ }^{\circledR}$. The multiblock copolymer solutions exhibited a reverse thermal gelation around body temperature. The gelation temperatures of the multiblock copolymer solutions were lower than those of the corresponding Pluronic ${ }^{\circledR}$ monomer at a particular concentration. The cytotoxicity of the synthesized polymer was lower comparing to its monomer. The solubility of hydrophobic anticancer drug, paclitaxel, was enhanced in the polymer solutions via micelle formation. The synthesized polymer was preferentially degraded in presence of MMP. Paclitaxel release was dependent on the enzyme concentration. These findings suggest that the synthesized polymer has the potential as controlled drug delivery system due to its unique phase transition and bioresponsive behavior.
\end{abstract}

\section{Keywords}

thermosensitive; hydrogel; Pluronic ${ }^{\circledR}$; biodegradable; matrix metalloproteinase-2

\footnotetext{
(C) 2011 Acta Materialia Inc. Published by Elsevier Ltd. All rights reserved.

Corresponding author: Seongbong Jo, Department of Pharmaceutics, School of Pharmacy, The University of Mississippi, University, MS 38677, USA, Tel: 1-662-915-5166, Fax: 1-662-915-1177, seongjo@olemiss.edu.

Publisher's Disclaimer: This is a PDF file of an unedited manuscript that has been accepted for publication. As a service to our customers we are providing this early version of the manuscript. The manuscript will undergo copyediting, typesetting, and review of the resulting proof before it is published in its final citable form. Please note that during the production process errors may be discovered which could affect the content, and all legal disclaimers that apply to the journal pertain.
} 


\section{INTRODUCTION}

The advance in technologies to engineer biomimetic materials has been an important breakthrough that would greatly influence human health care [1-3]. Careful fabrication of materials with precise consideration of the underlying cellular microenvironments made this approach suitable for various biomedical applications. Biomimetic materials have been consistently considered for drug delivery and tissue engineering [4-6]. These materials have frequently been obtained by incorporating bioactive molecules such as proteins and peptides $[1,7]$. Particularly, peptide conjugation has been proven as a vital approach to develop the biomimetic materials to suit the biomedical needs [8-10]. Several approaches have been tried to engineer these materials either to target the diseased tissue or to mimic the extracellular matrix [11-13].

Targeted delivery of anticancer drugs has been one of the pressing research areas using bioactive molecules. Anticancer therapeutic agents, such as methotrexate, paclitaxel and cisplatin, have been specifically delivered to tumor tissues by conjugating them to polymers using bioactive molecules [14-18]. However, most polymeric prodrugs carrying pendent cytotoxic drugs have been attached to polymer backbones via a peptide linker. The critical problems associated with the polymeric prodrugs include low drug loading capacity and altered physicochemical properties of the polymeric prodrug as a whole. Another drawback associated with the polymeric prodrug is the release of peptide fragment-modified drug rather than intact drug molecules, resulting in the reduced activity of parent drug [19]. An alternative to overcome the problems associated with these approaches would be local drug delivery systems with enhanced drug loading. Particularly, the local drug delivery systems based on amphiphilic thermosensitive polymers has been investigated in recent years [2022]. The thermosensitive polymer solution is a free-flowing fluid at room temperature allowing easy administration into the body. The polymer solution turns into gel depot upon injecting into the body, where the gel depot acts a drug reservoir [23]. In addition, the amphiphilic polymer can improve the solubility of insoluble drugs. From a clinical perspective, the injectable thermogels have a great benefit because they allow minimally invasive drug delivery directly to the diseased tissue.

Different thermogels were prepared with aqueous solutions of various polymeric materials such as chitosan, hyaluronic acid, alginate, Pluronic ${ }^{\circledR}$ copolymers and poly $(\mathrm{N}$ isopropylacrylamide)-based copolymers [24-26]. Among the reported thermosensitive polymers, Pluronic ${ }^{\circledR}$ copolymers, a class of polyethylene glycol-polypropylene glycolpolyethylene glycol (PEG-PPG-PEG) triblock copolymers, were extensively studied due to their drug loading capacity and acceptable biocompatibility [24, 27, 28]. It is worth mentioning about an anticancer micellar formulation based on Pluronic ${ }^{\circledR}$ L61 and F127, which has reached phase II clinical trials [29]. Besides the ability of the Pluronic ${ }^{\circledR}$ copolymers to form micelles and thermogels, they are capable of sensitizing multi-drug resistant cells and increasing drug transport across cellular barriers [30]. To overcome the undesirable gel properties associated with Pluronic ${ }^{\circledR}$ triblock copolymers such as weak mechanical strength and rapid erosion, multiblock copolymers made of PEG and PPG have been proposed for enhanced physicochemical properties [31-35]. A family of disulfide multiblock copolymers was synthesized from Pluronic ${ }^{\circledR}$ P65, P85 and P105 to prolong the gel duration and to undergo thiol-dependent degradation [32]. Interestingly, the thermogels of multiblock copolymers degraded and released paclitaxel in a glutathione-responsive manner. Recently, PoligoGel ${ }^{\circledR}$, a multiblock copolymer of PEG-PPG-PEG or PEGpolybutylene glycol(PBG)-PEG connected via dicarboxylic linkages has been used for the delivery of rat mesenchymal stem cells [33,34]. The thermogel was shown to have potential as a scaffold for the retention of cells at the target site. Novel thermogelling polymers based on multiblock poly(ether ester urethane)s have been engineered from poly[(R)-3- 
hydroxybutyrate] (PHB), PEG and PPG using hexamethylene diisocyanate as a coupling agent [35]. The thermogel showed improved gelation and drug release properties comparing to Pluronic ${ }^{\circledR}$ triblock copolymers. Even though several different thermogelling systems have been prepared, the drug release from the thermogels is mainly mediated by simple diffusion and non-specific hydrogel erosion. These obstacles necessitate uncovering a specific mechanism to control drug release from the thermogels. Matrix metalloprotenases (MMPs) can act as in situ controlling tools to regulate drug release from the thermogels. MMPs are zinc-dependent endopetidases that can cleave many of the extracellular matrix proteins. Many of the MMPs are found to be overexpressed and active during advanced stages of the cancer while they are minimally expressed in the normal tissue. Particularly, MMP2 and 9 (Type IV collagenases) which degrade extracellular matrices have been known to play a critical role in tumor progression, angiogenesis and metastasis [8]. Therefore, the combination of thermogelling property and enzyme sensitivity would provide a vital approach to engineer novel in-situ forming polymers that are suitable for bioresponsive local drug delivery.

A peptide specifically degraded by MMPs is either incorporated into or conjugated to a thermosensitive polymer to make a thermogel system which is sensitive to MMPs. A MMP13 sensitive peptide, QPQGLAK, has been incorporated into thermosensitive poly $(\mathrm{N}$ isopropyl acrylamide) hydrogel matrix $[11,12,36]$. The peptide in the hydrogel system provided a cross-linking structure while maintaining thermosensitive properties. In addition, the system showed concentration dependent degradation towards MMP2. Recently, an enzymatically degradable temperature sensitive polypeptide has been reported. The block copolymer, poly (ethylene glycol)-block-poly (alanine-co-phenyl alanine) (PEG-PAF), showed temperature sensitivity in water as well as degradability in the subcutaneous layer of rats [9]. Enzymes present in the subcutaneous layer such as cathepsin B, cathepsin C and elastase were assumed to be responsible for the degradation of polymer in vivo.

Here we report the synthesis of novel Pluronic ${ }^{\circledR}$-based multiblock copolymer connected via a MMP-2-sensitive peptide, Gly-Pro-Val-Gly-Leu-Ile-Gly-Lys-NH ${ }^{2}$ (GPVGLIGK-NH ${ }_{2}$ ). The hypothesis behind this project is that the combination of thermosensitive Pluronic ${ }^{\circledR}$ and MMP-sensitive peptide would result in a dual-stimuli-sensitive polymer which can form gel at body temperature and allow bioresponsive degradation in presence of MMP. Physical properties and in vitro cytotoxicity of the polymers were studied to assess in vivo applicability as a local drug delivery system. Finally, a chemotherapeutic agent, Paclitaxel (PTX), has been released to demonstrate the bioresponsive drug release from the thermogels.

\section{EXPERIMENTAL}

\subsection{Materials}

The peptide, GPVGLIGK- $\mathrm{NH}_{2}$, was synthesized by American Peptide Company (Vista, CA). Pluronic ${ }^{\circledR}$ P85 and P104 were kindly provided from BASF Chemical Company (Florham Park, NJ). Collagenase-IV was purchased from Sigma (Saint Louis, MO). PTX was obtained from LC Laboratories (Woburn, MA). Polystyrene standards of molecular weights 1, 4, 20, 50 and 100K were purchased from Polysciences, Inc. (Warrington, PA). All other chemicals were obtained from Fisher Scientific (Pittsburgh, PA) and used without further purification.

\subsection{Polymer synthesis}

2.2.1. Activation of triblock copolymer-Pluronic ${ }^{\circledR} \mathrm{P} 85$ or P104 (10 g) was dried by azeotropic distillation from $150 \mathrm{~mL}$ of anhydrous toluene. The dried Pluronic ${ }^{\circledR}$ was 
dissolved in $20 \mathrm{~mL}$ of anhydrous methylene chloride. About $2 \mathrm{~mL}$ of triethylamine (9.6 molar equiv.) was added to the reaction mixture at room temperature. After cooling the reaction mixture in an ice bath, 4-nitrophenyl chloroformate (NPC) (8.0 molar equiv.) was added. Initially, the mixture was allowed to react for $1 \mathrm{~h}$ at $0^{\circ} \mathrm{C}$. The reaction was continued overnight at room temperature under magnetic stirring. After all the solvent was removed, the activated Pluronic ${ }^{\circledR}$ (NPC-Pluronic ${ }^{\circledR}$ ) was dissolved in $50 \mathrm{~mL}$ of anhydrous ethyl acetate and filtered to remove precipitated triethylamine $\mathrm{HCl}$. The NPC-Pluronic ${ }^{\circledR}$ was reprecipitated from $50 \mathrm{~mL}$ of diethyl ether to remove unreacted NPC. This step was repeated twice to remove most of the unreacted NPC. Finally, the NPC-Pluronic ${ }^{\circledR}$ was dried under reduced pressure and kept in a desiccator until peptide coupling.

2.2.2. Coupling of the peptide to activated triblock copolymer-The peptide (100 $\mathrm{mg}$ ) and NPC-Pluronic ${ }^{\circledR}$ (1.1 molar amount to the peptide) were dissolved separately in 1 $\mathrm{mL}$ of dimethyl acetamide (DMA). NPC- Pluronic ${ }^{\circledR}$ solution was added to the peptide solution at room temperature by magnetic stirring. Triethylamine (5.0 molar amount to the peptide) was slowly added to the reaction mixture. The reaction was carried out for one day (at room temperature) or two days (first day at room temperature and second day at $50^{\circ} \mathrm{C}$ ) or three days (one day at room temperature and two days at $50^{\circ} \mathrm{C}$ ). Dry nitrogen was flushed to evaporate DMA from the reaction mixture. This crude multiblock copolymer was dissolved in water and dialyzed (molecular weight cut off: 6000-8000, Spectra/Por ${ }^{\circledR}$ ) against deionized water for two days with periodic media changes. The final product was freezedried to obtain polymer powder. Two different multiblock copolymers, MMP-P85 from Pluronic ${ }^{\circledR}$ P85 and MMP-P104 from Pluronic ${ }^{\circledR}$ P104, were synthesized with the yields of $80 \%$ and $89 \%$, respectively.

\subsection{Polymer characterization}

${ }^{1} \mathrm{H}$-nuclear magnetic resonance $\left({ }^{1} \mathrm{H}\right.$-NMR) was used to analyze the chemical structures of the synthesized polymers. Polymers were dissolved in either $\mathrm{CDCl}_{3}$ or $\mathrm{D}_{2} \mathrm{O}$ and the spectra were recorded on a 400MHz NMR spectrometer (Bruker Ultrashield ${ }^{\mathrm{TM}} 400$ PLUS, Germany). Waters gel permeation chromatography (GPC) system (Waters, Milford, MA) equipped with a binary pump (Waters 1525), a refractive index detector (Waters 2414) and a Styragel HR4E column $(300 \times 7.8 \mathrm{~mm}$ I.D., $5 \mu \mathrm{m}$ particle size $)$ was used to obtain the molecular weights and polydispersities of the polymers. Tetrahydrofuran was eluted at a flow rate of $1 \mathrm{~mL} / \mathrm{min}$ at $25^{\circ} \mathrm{C}$. Polystyrene standards (1000-50000 Da) were also run to obtain a calibration curve and the calibration curve was used to calculate the molecular weights of the polymers. Thermograms of the polymers were obtained from differential scanning calorimeter (DSC) (Perkin Elmer Diamond DSC, Waltham, MA). Melting temperatures of the polymers were determined from the thermograms thereafter. DSC was run in the temperature range of 0 to $50^{\circ} \mathrm{C}$ with a heating and cooling rate of $10^{\circ} \mathrm{C} / \mathrm{min}$. Initially, the samples were loaded in aluminum pans and equilibrated at $0^{\circ} \mathrm{C}$ for $5 \mathrm{~min}$. Dry nitrogen flow at a rate of $20 \mathrm{~mL} / \mathrm{min}$ was maintained throughout the analysis.

\subsection{Critical micelle concentration (CMC) of MMP-P104}

The CMCs of Pluronic ${ }^{\circledR}$ P104 and MMP-P104 were determined by a dye solubilization method using 1,6-diphenyl-1,3,5-hexatriene (DPH) [27]. Briefly, polymer solutions in the concentration range $1.0 \times 10^{-5}$ to $10 \mathrm{wt} \%$ were prepared. DPH solution $(10 \mu \mathrm{L}, 0.4 \mathrm{mM}$ in methanol) was added to $1.0 \mathrm{~mL}$ of each polymer solution. The polymer solutions were incubated at $25^{\circ} \mathrm{C}$ for $24 \mathrm{~h}$ in a dark place. The absorbance values of the test solutions were recorded on a Lambda EZ201 UV spectrophotometer (Perkin Elmer, Waltham, MA) at 377 and $391 \mathrm{~nm}$. A graph was drawn plotting the difference between two absorbance values on vertical axis and concentration on horizontal axis. 


\subsection{DSC of polymer solutions}

DSC thermographs of Pluronic ${ }^{\circledR}$ P104 and MMP-P104 solutions were obtained in the concentration range of 1 to $25 \mathrm{wt} \%$. Sample solutions were prepared by dissolving specific amount of polymer in deionized water with gentle stirring at $4^{\circ} \mathrm{C}$. Accurately weighed sample solutions (6 mg) were placed in aluminum cells and reference cells were made up with same amount of deionized water. DSC was run in the temperature range of -10 to $50^{\circ} \mathrm{C}$ at a rate of $5^{\circ} \mathrm{C} / \mathrm{min}$. Samples were thermally equilibrated at $-10^{\circ} \mathrm{C}$ for $15 \mathrm{~min}$ before the scanning.

\subsection{Circular dichroism (CD) spectroscopy}

The CD spectra of MMP-P104 and peptide solutions were analyzed in the wavelength range of 250 to $190 \mathrm{~nm}$ using a CD spectrometer (Olis ${ }^{\circledR}$ DSM 20 CD Spectrophotometer, Bogart, GA). MMP-P104 and peptide solutions were prepared at 0.1 and $0.01 \mathrm{wt} \%$, respectively. The sample solutions were equilibrated at $4{ }^{\circ} \mathrm{C}$ overnight before the analysis. A cuvette (path length-1 $\mathrm{mm}$ ) was charged with a sample solution and CD spectra were recorded at 15, 25, 35 and $45^{\circ} \mathrm{C}$. Molar ellipticity of all the samples was calculated after a blank reference of water was subtracted from the raw data.

\subsection{In vitro cytotoxicity}

In vitro cytotoxicity study was performed using 3-(4,5-dimethylthiazol-2-yl)-2,5-diphenyl tetrazolium bromide (MTT) on HT1080 fibrosarcoma cells [37]. The cells were cultured in Roswell Park Memorial Institute medium (RPMI). The RPMI was supplemented with 10\% fetal bovine serum (FBS) and antibiotics. The cultured cells in 96 -well plates $\left(5 \times 10^{3}\right.$ cells/ well) were grown for $24 \mathrm{~h}$ at $37^{\circ} \mathrm{C}$. The culture medium was replaced with MMP-P104 solution $(100 \mu \mathrm{L}, 0.05-1.00 \mathrm{wt} \%)$ in serum-free Dulbecco's Modified Eagle's Medium (DMEM). The cells were incubated for $4 \mathrm{~h}$ in serum-free DMEM $(100 \mu \mathrm{L})$ followed by $12 \mathrm{~h}$ incubation in $200 \mu \mathrm{L}$ DMEM containing $10 \%$ FBS. After $16 \mathrm{~h}$ of total incubation, the test solutions were replaced with fresh media $(200 \mu \mathrm{L})$ and $5 \mathrm{mg} / \mathrm{mL}$ MTT solution $(20 \mu \mathrm{L})$. The cells were incubated for $4 \mathrm{~h}$ in MTT solution. Later, the MTT solution was replaced with $400 \mu \mathrm{L}$ dimethyl sulfoxide to dissolve internalized purple formazan crystals. To measure the absorbance at $570 \mathrm{~nm}$ on a VICTOR3 VTM Multilabel Counter (Perkin Elmer, MA, USA), $150 \mu \mathrm{L}$ of the solution was transferred from each well into a fresh 96-well plate. Cell viability was calculated as compared to phosphate buffered saline (PBS)-treated cells (100 $\%$ survival).

\subsection{Thermal gelation of polymeric solutions}

2.8.1. Test tube inverting method-Polymer solutions were prepared by dissolving them in deionized water at $4^{\circ} \mathrm{C}$. A series of polymer solutions at concentrations of 5, 10, 15, 20 and $25 \mathrm{wt} \%$ were prepared. Scintillation vials $(4 \mathrm{~mL})$ were loaded with $1 \mathrm{~mL}$ of the polymer solution and incubated at $4^{\circ} \mathrm{C}$ overnight. The sol-gel and gel-sol phase transition temperatures of the each polymer solution were determined with increments of $2^{\circ} \mathrm{C}[24,38]$. The experiment was conducted in the temperature range of 15 to $80^{\circ} \mathrm{C}$. The temperature at which a polymer solution stopped flowing upon a tube inversion was recorded as gelation temperature.

2.8.2. Falling ball method-MMP-P104 solutions at concentrations of $10,15,20$ and 25 $\mathrm{wt} \%$ were prepared in deinonized water. NMR tube of diameter $4.0 \mathrm{~mm}$ was filled with the polymer solution. The polymer solution was incubated at $10^{\circ} \mathrm{C}$ for $20 \mathrm{~min}$. A steel ball (diameter $(D)=1.97 \mathrm{~mm}$, density $\left.\left(\rho_{\mathrm{s}}\right)=7.97 \mathrm{~g} / \mathrm{mL}\right)$ was dropped through the polymer solution. The time $(t)$ required for the steel ball to fall a specified distance $(d=3 \mathrm{~cm})$ was measured with a temperature increment of $2^{\circ} \mathrm{C}$ per step for each polymer concentration. The 
polymer solutions were equilibrated for $20 \mathrm{~min}$ at each temperature. The intersection of extrapolated lines of travel time of the steel ball on a graph plotted between temperature and the transit time gives the sol-gel transition temperature of the polymer solution [39]. The dynamic viscosity $(\mu)$ was calculated using the following formula

$$
\mu=\left(\gamma_{s}-\gamma_{\mathrm{f}}\right) D^{2} /(18 v)
$$

Where, the velocity of the falling ball $(v)=d / t$, specific gravity of the sphere $\left(\gamma_{\mathrm{s}}\right)=\rho_{\mathrm{s}} g$, specific gravity of the polymer solution $\left(\gamma_{\mathrm{f}}\right)=\rho_{\mathrm{f}} g$, and acceleration due to gravity $(g)=980$ $\mathrm{cm} / \mathrm{s}^{2}$. The density of the polymer solution $\left(\rho_{\mathrm{f}}\right)$ was assumed to be $1.0 \mathrm{~g} / \mathrm{cm}^{3}$.

\subsection{MMP-P104 degradation}

The MMP-P104 solution was prepared at a concentration of $25 \mathrm{wt} \%$ in deinonized water. The polymer solution $(50 \mu \mathrm{L})$ was placed in $1 \mathrm{~mL}$ vials and the vials were kept at $4^{\circ} \mathrm{C}$ overnight. The polymer solutions were incubated at $37^{\circ} \mathrm{C}$ for $15 \mathrm{~min}$ for gelation. Phosphate buffer $(0.1 \mathrm{~mL}, 50 \mathrm{mM})$ was added to first three vials (control). In another three vials, phosphate buffer containing collagenase-IV $(250 \mu \mathrm{g} / \mathrm{mL})$ was added. The degradation of the gels was stopped by freezing the gels at predetermined time intervals. The frozen samples were then freeze-dried to get the degraded polymer. GPC was run to check the molecular weight distribution of the degraded polymer.

\subsection{In vitro paclitaxel release}

MMP-P104 $(250 \mathrm{mg})$ was dissolved in $200 \mu \mathrm{L}$ of the acetone. After partial removal of acetone by dry nitrogen flushing, $20 \mu \mathrm{L}$ of the acetone containing 500 $\mu \mathrm{g}$ of PTX was added to the polymer solution. By continuously mixing the polymer-drug mixture, the acetone was removed by dry nitrogen flushing. Finally, the polymer-drug mixture was vacuum dried in vacuum for $4 \mathrm{~h}$ to remove the acetone completely. The MMP-P104-PTX mixture was dissolved in $750 \mu \mathrm{L}$ water with vigorous stirring at $4^{\circ} \mathrm{C}$. The polymer-drug solution $(0.2$ $\mathrm{mL}$ ) was placed in each $2 \mathrm{~mL}$ vial and allowed for gelation at $37^{\circ} \mathrm{C}$. The gels were equilibrated at this temperature for $15 \mathrm{~min}$. Phosphate buffer $(1.6 \mathrm{~mL}, 50 \mathrm{mM})$ including $1 \%$ w/v Tween 80 was added to first set of vials (control). Phosphate buffer $(1.6 \mathrm{~mL}, 50 \mathrm{mM})$ composed of collagenase-IV $(1,10,50$ and $250 \mu \mathrm{g} / \mathrm{mL})$, Tween $80(1 \% \mathrm{w} / \mathrm{v})$, calcium chloride $(0.5 \mathrm{mM})$ and sodium azide $(0.2 \mathrm{mg} / \mathrm{mL})$ was added to another set of vials. While incubating at $37^{\circ} \mathrm{C}$, samples were collected and total medium was replaced for every $12 \mathrm{~h}$ to maintain perfect sink conditions. The samples were analyzed for PTX by high performance liquid chromatography (HPLC). Waters HPLC system (Waters, Milford, MA) was equipped with a binary pump, dual absorbance detector, and XTerra ${ }^{\circledR} \mathrm{RP} 18,5 \mu \mathrm{m}$ column $(4.6 \times 150$ $\mathrm{mm})$. A mixture of acetonitrile and water in the ratio of 55:45 was eluted at a flow rate of 1 $\mathrm{mL} / \mathrm{min}$ at $25^{\circ} \mathrm{C}$ and the detection wavelength was set to $230 \mathrm{~nm}$.

\section{RESULTS \& DISCUSSION}

Multiblock copolymers (MMP-P85 and MMP-P104) were synthesized by conjugating thermosensitive Pluronic ${ }^{\circledR}$ (P85 and P104), a group of triblock copolymer of PEG-PPGPEG, to a MMP-sensitive peptide (GPVGLIGK-NH ${ }_{2}$ ). The synthesis involves a two-step reaction as described in Scheme 1. The ${ }^{1} \mathrm{H}-\mathrm{NMR}$ spectra of Pluronic ${ }^{\circledR} \mathrm{P} 104$ and purified NPC-Pluronic ${ }^{\circledR}$ were shown in Figure 1. The activation of Pluronic ${ }^{\circledR}$ was confirmed by the characteristic proton peaks of 4-nitrophenyl carbonate ranging from 7.4 to $8.4 \mathrm{ppm}$ in ${ }^{1} \mathrm{H}$ NMR spectrum [40]. Figure 1A shows the proton peak of hydroxyl protons (c) at each end of the Pluronic ${ }^{\circledR}$. The hydroxyl proton peak was disappeared in the NMR spectrum (Figure 
1B) upon the activation of Pluronic ${ }^{\circledR}$. In addition, the appearance of proton peak of the methylene group (f) at 4.45ppm confirmed the successful activation of the Pluronic ${ }^{\circledR}$.

Several peptide sequences such as GPLGIAGQ, GPQGPAGQ, PVGLIG, and CGLDD have shown MMP susceptibility [13, 14, 19]. An octapeptide sequence (GPVGLIGK-NH ${ }_{2}$ ) has been synthesized to conjugate to the Pluronic ${ }^{\circledR}$ moiety. An MMP-sensitive hexapeptide (PVGLIG) [19] was modified at the ends with two amino acids (glycine and lysine) to provide amine functional groups on both ends. The modification in the peptide would allow the conjugation reaction to the terminals while maintaining MMP-sensitive cleavage of the peptide at -GL- [41]. The terminal amino groups of the peptide allowed the linear oligomerization between the peptide and NPC- Pluronic ${ }^{\circledR}$. As Pluronic ${ }^{\circledR}$ of molecular weight $\sim 5000$ may not be easily accessible for the oligomerizaion, the reaction time and temperature were increased to check the effect of these parameters on the final molecular weight of MMP-P104. Table 1 summarizes the molecular weights of MMP-P104 at different reaction conditions. The molecular weight of MMP-P104 slightly increased on increasing the reaction time and temperature. Figure 1-C shows the ${ }^{1} \mathrm{H}-\mathrm{NMR}$ spectrum of MMP-P104. The oligomerization was confirmed by the characteristic proton peaks of peptide and Pluronic $^{\circledR}$ in the final polymer. The proton peaks at $g$ to $v$ shows the presence of peptide and its conjugation to Pluronic ${ }^{\circledR}$.

Determined molecular characteristics of Pluronic ${ }^{\circledR}$ copolymers, MMP-P85 and MMP-P104 were summarized in Table 2. The calculated molecular weights of MMP-P85 and MMPP104 were found to be 15290 and $23540 \mathrm{~g} / \mathrm{mol}$ respectively. The molecular weight analysis indicates that MMP-P85 and MMP-P104 are multiblock copolymers with 2.06 and 2.76 units of Pluronic ${ }^{\circledR}$ P85 and Pluronic ${ }^{\circledR}$ P104 respectively. Comparing to previously reported Pluronic ${ }^{\circledR}$-based multiblock copolymers [24], multiblock copolymers with relatively low molecular weights were achieved because of relatively high molecular weight peptide ( 740 $\mathrm{g} / \mathrm{mol}$ ) which might limit the access of the nitro group at the end of the Pluronic ${ }^{\circledR}$ to the amine group in the peptide during oligomerization. According to DSC data, the melting temperatures $\left(T_{m}\right)$ of MMP-P85 and MMP-P104 were found to be $28.5( \pm 1.8)$ and 30.9 $( \pm 2.2){ }^{\circ} \mathrm{C}$. The $T_{m}$ values of multiblock copolymers are lowered comparing to the $T_{m}$ values of Pluronic ${ }^{\circledR}$ monomers. This lowering of the $T_{m}$ values of MMP-P85 and MMP-P104 may be due to the interrupted polymer packing by the incorporation of a peptide in the polymer structure [24].

The relatively high molecular weight of MMP-P104 made this multiblock copolymer an interested candidate comparing to MMP-P85. So, the further characterization was mainly performed with MMP-P104. A hydrophobic dye (DPH) solubilization method was used to measure the CMC of MMP-P104 [24, 27]. The absorbance of DPH has sharply increased at CMC of the MMP-P104 (Figure 2). The CMC was calculated by extrapolating the absorbance versus logarithmic concentration. The CMC of MMP-P104 was found to be $0.208( \pm 0.012) \mathrm{wt} \%$ which is slightly lower than the CMC of Pluronic ${ }^{\circledR} \mathrm{P} 104(0.300$ $( \pm 0.009) \mathrm{wt} \%)$. This lowering of the CMC is mainly attributed to the increased molecular weight of MMP-P104. This can be explained in two ways. First, at a given PPO/PEO ratio, higher molecular weight Pluronic ${ }^{\circledR}$ polymers form micelles more readily than the lower molecular weight polymers [42]. Second, the easy micelle formation is favored for multiblock copolymer as covalently bonded PPGs facilitate easy hydrophobic core formation during micelle structuring [27].

The polymer solutions were further characterized for critical micellization temperature (CMT). The micellization process is characterized by endothermic peak during the heating cycle in DSC. The onset temperature at which micelles start to form is considered as the CMT at the particular polymer concentration. Figure 3 shows the comparison between CMT 
values of Pluronic ${ }^{\circledR}$ P104 and MMP-P104 solutions at different concentrations. The trend in CMT changes with polymer concentration was in accordance with phase transition of Pluronic ${ }^{\circledR}$ P104 [42, 43]. The CMT of MMP-P104 slightly lowered than that of Pluronic ${ }^{\circledR}$ P104 at each polymer concentration. This is mainly due to the higher molecular weight of the multiblock copolymer comparing to Pluronic ${ }^{\circledR} \mathrm{P} 104$. High molecular weight block polymers are known to be more favorable for micelle formation than low molecular weight polymers [42].

Secondary structures of MMP-P104 and peptide in solution were analyzed using CD spectroscopy as a function of temperature. Formation of $\alpha$ - helices (one positive band centered at $\sim 195 \mathrm{~nm}$ and two negative bands between 205-225 nm) or $\beta$ - sheets (one positive band centered at $\sim 195 \mathrm{~nm}$ and one negative band between $210-220 \mathrm{~nm}$ ) or random coils (one negative band centered at $\sim 195 \mathrm{~nm}$ and one positive band centered at $\sim 215 \mathrm{~nm}$ ) will show characteristic CD spectra [8]. Spectra of both peptide and MMP-P104 suggested the random coil arrangement of MMP-sensitive peptide in the multiblock copolymer in an aqueous environment. Pluronic ${ }^{\circledR}$ did not show a considerable effect on the random coil arrangement of peptide in water. Figure 4 shows the CD spectra of MMP-P104 at 15, 25, 35 and $45^{\circ} \mathrm{C}$. As the temperature of polymer solutions increased, no visible change in the $\mathrm{CD}$ spectra was observed. Also, the effect of temperature on the random coil arrangement of peptide is very minimum (supporting information: Figure S4) indicating that the temperature does not affect the secondary structural arrangement of the octapeptide in MMP-P104.

Cytotoxicity of Pluronic ${ }^{\circledR}$ P104 and MMP-P104 was assessed by MTT assay using HT1080 fibrosarcoma cells. As HT1080 cells are known to express different types of MMPs, especially MMP 2 and 9, they were chosen for the assessment of the cytotoxicity [44, 45]. Figure 5 shows the results of MTT assay in the polymer concentration ranging from 0.05 to $1.00 \mathrm{wt} \%$. It is shown that MMP-P104 resulted in a greater cell viability comparing to monomeric Pluronic ${ }^{\circledR} \mathrm{P} 104$. The difference in cytotoxicity can be attributed to molecular weight difference between MMP-P104 and Pluronic ${ }^{\circledR}$ P104. Previously, a Pluronic ${ }^{\circledR}$ P104 based multiblock copolymer (MBCP 2) of molecular weight $\sim 40000$ showed cell viability of $>80 \%$ [24]. Therefore the increase in polymer molecular weight would be a vital means to improve the biocompatibility of MMP-P104. Biocompatible MMP-104 with increased molecular weight would provide an ideal cancer drug delivery platform which can achieve bioresponsive drug release as well as enhanced cytotoxicity to cancer cells with the sensitizing effect from released Pluronic ${ }^{\circledR}$ P104.

The fundamental properties such as sol-gel and gel-sol transition temperatures of Pluronic ${ }^{\circledR}$ P104 and MMP-P104 polymer solutions were evaluated by test tube inverting method and falling ball method. Figure 6 shows the phase diagram of MMP-P104 and Pluronic ${ }^{\circledR}$ P104 at different polymer concentrations. The sol-gel transition temperatures determined by test tube inverting method are in good agreement with the values determined by falling ball method. Due to an extended equilibration time during the execution of falling ball method, a slight difference in gelation temperature was observed between two methods. At all polymer concentrations tested for gelation, MMP-P104 solutions were free flowing liquids at room temperature which could be easily injected through 25 -guage needle. Upon increasing the temperature to $37^{\circ} \mathrm{C}$, the solution immediately turned into gel depending on the polymer concentration. Figure 7 shows the change in viscosities with temperature of MMP-P104 solutions at different polymer concentrations. The viscosities are below $500 \mathrm{~g} / \mathrm{cm} \cdot \mathrm{sec}^{-1}$ during the "sol" state where as they ranged between 1000-9000 g/cm. $\mathrm{sec}^{-1}$ during the "gel" phase for all the measured concentrations. MMP-P104 solutions showed sol-gel-sol transition in the range of 10-25 wt \% . But, the Pluronic ${ }^{\circledR}$ P104 (25wt\%) solution showed solgel-sol-gel-sol transition on increasing the temperature. Formation of isotropic or cubic crystalline phases is responsible for gelation at low temperature whereas formation of multi- 
phases (cubic/hexagonal/lamellar) cause gelation at high temperature [46]. The sol-gel transition temperatures of MMP-P104 were lowered comparing to Pluronic ${ }^{\circledR} \mathrm{P} 104$ at particular concentration. For example, at $25 \mathrm{wt} \%$ the gelation temperature of Pluronic ${ }^{\circledR}$ $\mathrm{P} 104$ was $68.5^{\circ} \mathrm{C}$ whereas the gelation temperature of MMP-P104 was $30.7^{\circ} \mathrm{C}$. In addition to the sol-gel transition, the critical gelation concentration (CGC) of MMP-P104 was also lowered comparing to the CGC of Pluronic ${ }^{\circledR} \mathrm{P} 104$. The alteration in the gelation properties was mainly attributed to the increase in the micelle size due to increased molecular weight of MMP-P104 comparing to Pluronic ${ }^{\circledR}$ P104 (supporting information: Table S2). Therefore, the larger micelle size resulting from multiblock copolymer might be the reason for lower CGC with facile and/or extensive polymer interactions comparing to Pluronic ${ }^{\circledR}$ P104 micelles.

Figure 8 shows the GPC chromatographs of degraded MMP-P104 in presence or absence of MMP. An MMP concentration of $250 \mu \mathrm{g} / \mathrm{mL}$ was chosen to study the polymer degradation in a facilitated condition. MMP-P104 degraded rapidly in presence of MMP showing complete polymer degradation within $24 \mathrm{~h}$ while the polymer degraded much slower in the absence of MMP. Complete polymer degradation was observed at the end of day 12 without the enzyme. GPC was also run on Pluronic ${ }^{\circledR} \mathrm{P} 104$ to compare the changes in

chromatographs. The chromatograph of completely degraded MMP-P104 was similar to that of Pluronic ${ }^{\circledR}$ P104 indicating that the multiblock copolymer degraded into its monomeric units. Considering the MMP-cleavable site in the peptide, the possible degradation products of multiblock copolymer would be the Pluronic ${ }^{\circledR}$ monomers with four amino acids on both the terminals. However, remaining peptide segments will be eventually degraded into amino acids by proteases in the body.

MMP-P104 solutions demonstrated quick gelation which occurred within a minute below body temperature at a polymer concentration of $25 \mathrm{wt} \%$. Based on this observation, $25 \mathrm{wt} \%$ was selected for in vitro PTX release. The achieved PTX concentration in $25 \mathrm{wt} \% \mathrm{MMP}$ P104 solution was found to be $0.847( \pm 0.019) \mathrm{mg} / \mathrm{mL}$. The achieved PTX concentration was nearly 200-fold increase in PTX solubility in water with a PTX concentration increase from $0.004 \mathrm{mg} / \mathrm{mL}$ to $0.847 \mathrm{mg} / \mathrm{mL}$ in the presence of the polymer. PTX release from the MMPsensitive thermogel was investigated at four different MMP concentrations as well as in MMP free media. Release profiles have been summarized in Figure 9. PTX release lasted for 2, 5 and 8 days at MMP concentrations of 50,10, and $1 \mu \mathrm{g} / \mathrm{mL}$, respectively. Rapid drug release due to the erosion of the gels was observed in presence of MMP. Based on the consistency between PTX release and polymer degradation, it is notable that erosion played a main role in the drug release in presence of MMP. On the other hand, both erosion and diffusion have caused sustained drug release up to 13 days in the absence of MMP.

Precise drug release from an in-situ formed hydrogel depot to achieve a local therapeutic drug concentration is a difficult task since there is no viable mechanism to control drug release once it forms a depot. The hydrogel depot is expected to monotonously release incorporated drug at a predetermined rate until incorporated drug is completely exhausted. The presence of an extra mechanism that is able to control drug release even beyond in-situ depot formation and secure a therapeutic level of drug will be highly desirable for successful local drug delivery particularly for detrimental diseases such as cancers. MMP-sensitive thermogels were tested for cooperative drug release by diffusion and enzymatic hydrogel degradation which may be useful for the achievement of effective local drug delivery potentially for cancers. The thermogel was challenged with an alternating medium change to simulate an MMP-elevation in cancer. As shown in Figure 10, the thermogel immediately increased PTX release upon a medium replacement from MMP-free medium to MMPcontaining medium. Upon an addition of MMP at a concentration of $250 \mu \mathrm{g} / \mathrm{mL}$, cumulative PTX release was dramatically increased from $27 \%$ to complete drug release within $24 \mathrm{hr}$. 
The MMP-sensitive PTX release demonstrated in Figures 9 and 10 is completely in accordance with the polymer degradation presented in Figure 8. Marked increase in drug release from the MMP-sensitive thermogel suggests the capability of MMP-sensitive thermogel as a bioresponsive local drug delivery platform which would be particularly applicable for cancer drug delivery.

\section{CONCLUSIONS}

MMP-sensitive thermogelling polymers have been successfully synthesized for potential drug delivery applications by incorporating an MMP-sensitive peptide into an amphiphilic multiblock copolymer. The aqueous solution of the synthesized polymer underwent gelation at body temperature. In addition, the gelation temperature of the polymer solutions varied depending on the polymer concentration. The cytotoxicity of the synthesized polymer was lower comparing to the corresponding monomer. The secondary structure of the peptide inside the thermogel was confirmed to be a random coil arrangement. The polymer was rapidly degraded in presence of MMP. The synthesized polymer greatly enhanced the solubility of a hydrophobic cancer drug, paclitaxel. The polymer gels exhibited the release of incorporated drug in a bioresponsive manner.

\section{Supplementary Material}

Refer to Web version on PubMed Central for supplementary material.

\section{Acknowledgments}

We acknowledge the research facility support from the NIH National Center for Research Resources through C06 RR-14503-01 and P20 RR021929.

\section{REFERENCES}

1. Kim JK, Anderson J, Jun HW, Repka MA, Jo S. Self-assembling peptide amphiphile-based nanofiber gel for bioresponsive cisplatin delivery. Mol Pharm. 2009; 6:978-985. [PubMed: 19281184]

2. Kopecek J, Yang J. Peptide-directed self-assembly of hydrogels. Acta Biomater. 2009; 5:805-816. [PubMed: 18952513]

3. Shin H, Jo S, Mikos AG. Biomimetic materials for tissue engineering. Biomaterials. 2003; 24:43534364. [PubMed: 12922148]

4. Lin Z, Duan Z, Guo X, Li J, Lu H, Zheng Q, Quan D, Yang S. Bone induction by biomimetic PLGA-(PEG-ASP)n copolymer loaded with a novel synthetic BMP-2-related peptide in vitro and in vivo. J Control Release. 2010; 144:190-195. [PubMed: 20184932]

5. Ma PX. Biomimetic materials for tissue engineering. Adv Drug Deliv Rev. 2007; 60:184-198. [PubMed: 18045729]

6. Drotleff S, Lungwitz U, Breunig M, Dennis A, Blunk T, Tessmar J, Göpferich A. Biomimetic polymers in pharmaceutical and biomedical sciences. Eur J Pharm Biopharm. 2004; 58:385-407. [PubMed: 15296963]

7. Krishna OD, Kiick KL. Protein- and peptide-modified synthetic polymeric biomaterials. Biopolymers. 2010; 94:32-48. [PubMed: 20091878]

8. Chau Y, Luo Y, Cheung AC, Nagai Y, Zhang S, Kobler JB, Zeitels SM, Langer R. Incorporation of a matrix metalloproteinase-sensitive substrate into self assembling peptides a model for biofunctional scaffolds. Biomaterials. 2008; 29:1713-1719. [PubMed: 18192002]

9. Jeong Y, Joo MK, Bahk KH, Choi YY, Kim HT, Kim WK, Lee HJ, Sohn YS, Jeong B. Enzymatically degradable temperature-sensitive polypeptide as a new in-situ gelling biomaterial. J Control Release. 2009; 137:25-30. [PubMed: 19306901] 
10. Kraehenbuehl TP, Zammaretti P, Van der Vlies AJ, Schoenmakers RG, Lutolf MP, Jaconi ME, Hubbell JA. Three-dimensional extracellular matrix-directed cardioprogenitor differentiation: Systematic modulation of a synthetic cell-responsive PEG-hydrogel. Biomaterials. 2008; 29:27572766. [PubMed: 18396331]

11. Chung EH, Gilbert M, Virdi AS, Sena K, Sumner DR, Healy KE. Biomimetic artificial ECMs stimulate bone regeneration. J Biomed Mater Res A. 2006; 79A:815-826. [PubMed: 16886222]

12. Kim S, Chung EH, Gilbert M, Healy KE. Synthetic MMP-13 degradable ECMs based on poly(Nisopropylacrylamide-co-acrylic acid) semi-interpenetrating polymer networks. I. Degradation and cell migration. J Biomed Mater Res A. 2005; 75:73-88. [PubMed: 16049978]

13. Kratz F, Drevs J, Bing G, Stockmar C, Scheuermann K, Lazar P, Unger C. Development and in vitro efficacy of novel MMP2 and MMP9 specific doxorubicin albumin conjugates. Bio Med Chem Lett. 2001; 11:2001-2006.

14. Chau Y, Dang NM, Tan FE, Langer R. Investigation of targeting mechanism of new dextranpeptide-methotrexate conjugates using biodistribution study in matrix metalloproteinaseoverexpressing tumor xenograft model. J Pharm Sci. 2006; 95:542-551. [PubMed: 16419048]

15. Sugahara S, Kajiki M, Kuriyama H, Kobayashi T. Complete regression of xenografted human carcinoma by a paclitaxel-carboxymethyl dextran conjugate (AZ10992). J Control Release. 2007; 117:40-50. [PubMed: 17126446]

16. Tauro JR, Gemeinhart RA. Matrix metalloprotease triggered delivery of cancer chemotherapeutics from hydrogel matrixes. Bioconjug Chem. 2005; 16:1133-1139. [PubMed: 16173790]

17. Erez R, Segal E, Miller K, Satchi-Fainaro R, Shabat D. Enhanced cytotoxicity of a polymer-drug conjugate with triple payload of paclitaxel. Bioorg Med Chem. 2009; 17:4327-4335. [PubMed: 19482477]

18. Jun YJ, Min JH, Ji da E, Yoo JH, Kim JH, Lee HJ, Jeong B, Sohn YS. A micellar prodrug of paclitaxel conjugated to cyclotriphosphazene. Bioorg Med Chem Lett. 2008; 18:6410-6413. [PubMed: 18990574]

19. Chau Y, Tan FE, Langer R. Synthesis and Characterization of Dextran-Peptide-Methotrexate Conjugates for Tumor Targeting via Mediation by Matrix Metalloproteinase II and Matrix Metalloproteinase IX. Bioconju Chem. 2004; 15:931-941.

20. Chen S, Pederson D, Oak M, Singh J. In vivo absorption of steroidal hormones from smart polymer based delivery systems. J Pharm Sci. 2010; 99:3381-3388. [PubMed: 20213838]

21. Li X, Zheng X, Wei X, Guo G, Gou M, Gong C, Wang X, Dai M, Chen L, Wei Y, Qian Z. A novel composite drug delivery system: honokiol nanoparticles in thermosensitive hydrogel based on chitosan. J Nanosci Nanotechnol. 2009; 9:4586-4592. [PubMed: 19928122]

22. Gong CY, Shi S, Peng XY, Kan B, Yang L, Huang MJ, Luo F, Zhao X, Wei YQ, Qian ZY. Biodegradable thermosensitive injectable PEG-PCL-PEG hydrogel for bFGF antigen delivery to improve humoral immunity. Growth Factors. 2009; 27:377-383. [PubMed: 19919526]

23. Zentner GM, Rathi R, Shih C, McRea JC, Seo MH, Oh H, Rhee BG, Mestecky J, Moldoveanu Z, Morgan M, Weitman S. Biodegradable block copolymers for delivery of proteins and waterinsoluble drugs. J Control Release. 2001; 72:203-215. [PubMed: 11389999]

24. Garripelli VK, Kim J-K, Namgung R, Kim WJ, Repka MA, Jo S. A novel thermosensitive polymer with $\mathrm{pH}$-dependent degradation for drug delivery. Acta Biomater. 2010; 6:477-485. [PubMed: 19596093]

25. Aaron DG, Tarabar D, Seidel RH, Elstad NL, Fowers KD. Phase 2: a dose-escalation study of OncoGel (ReGel/paclitaxel), a controlled-release formulation of paclitaxel, as adjunctive local therapy to external-beam radiation in patients with inoperable esophageal cancer. Anticancer Drugs. 2009; 20:89-95. [PubMed: 19209024]

26. Vukelja SJ, Anthony SP, Arseneau JC, Berman BS, Casey Cunningham C, Nemunaitis JJ, Samlowski WE, Fowers KD. Phase 1 study of escalating-dose OncoGel((R)) $(\operatorname{ReGel}((\mathrm{R})) /$ paclitaxel) depot injection, a controlled-release formulation of paclitaxel, for local management of superficial solid tumor lesions. Anticancer Drugs. 2007; 18:283-289. [PubMed: 17264760]

27. Ahn JS, Suh JM, Lee M, Jeong B. Slow eroding biodegradable multiblock poloxamer copolymers. Polym Int. 2005; 54:842-847. 
28. Batrakova EV, Kabanov AV. Pluronic block copolymers: evolution of drug delivery concept from inert nanocarriers to biological response modifiers. J Control Release. 2008; 130:98-106. [PubMed: 18534704]

29. Valle JW, Lawrance J, Brewer J, Clayton A, Corrie P, Alakhov V, Ranson M. A phase II, window study of SP1049C as first-line therapy in inoperable metastatic adenocarcinoma of the oesophagus. J Clin Oncol. 2004; 22:4195.

30. Minko T, Batrakova EV, Li S, Li Y, Pakunlu RI, Alakhov VY, Kabanov AV. Pluronic block copolymers alter apoptotic signal transduction of doxorubicin in drug-resistant cancer cells. J Control Release. 2005; 105:269-278. [PubMed: 15939500]

31. Ruel-Gariépy E, Leroux JC. In situ-forming hydrogels--review of temperature-sensitive systems. Eur J Pharm Biopharm. 2004; 58:409-426. [PubMed: 15296964]

32. Sun KH, Sohn YS, Jeong B. Thermogelling poly(ethylene oxide-b-propylene oxide-b-ethylene oxide) disulfide multiblock copolymer as a thiol-sensitive degradable polymer. Biomacromolecules. 2006; 7:2871-2877. [PubMed: 17025364]

33. Borden BA, Yockman J, Kim SW. Thermoresponsive hydrogel as a delivery scaffold for transfected rat mesenchymal stem cells. Mol Pharm. 2010; 7:963-968. [PubMed: 20583814]

34. Seo, MH.; Kim, BO.; Shim, MS.; Lee, SJ. Biodegradable multi-block polymeric composition capable of sol-gel transition and pharmaceutical composition comprising the same. US Patent. WO/2005/014067. 2005.

35. Loh XJ, Goh SH, Li J. Hydrolytic degradation and protein release studies of thermogelling polyurethane copolymers consisting of poly[(R)-3-hydroxybutyrate], poly(ethylene glycol), and poly(propylene glycol). Biomaterials. 2007; 28:4113-4123. [PubMed: 17573109]

36. Kim S, Healy KE. Synthesis and characterization of injectable poly(n-isopropylacrylamide-coacrylic acid) hydrogels with proteolytically degradable cross-links. Biomacromolecules. 2003; 4:1214-1223. [PubMed: 12959586]

37. Son S, Kim WJ. Biodegradable nanoparticles modified by branched polyethylenimine for plasmid DNA delivery. Biomaterials. 2010; 31:133-143. [PubMed: 19783041]

38. Jo S, Kim J, Kim SW. Reverse thermal gelation of aliphatically modified biodegradable triblock copolymers. Macromol Biosci. 2006; 6:923-928. [PubMed: 17099865]

39. Chung Y-M, Simmons KL, Gutowska A, Jeong B. Sol-Gel transition temperature of PLGA-g-PEG aqueous solutions. Biomacromolecules. 2002; 3:511-516. [PubMed: 12005522]

40. Jo S, Shin H, Mikos AG. Modification of oligo(poly(ethylene glycol) fumarate) macromer with a GRGD peptide for the preparation of functionalized polymer networks. Biomacromolecules. 2001; 2:255-261. [PubMed: 11749181]

41. Turk BE, Huang LL, Piro ET, Cantley LC. Determination of protease cleavage site motifs using mixture-based oriented peptide libraries. Nat Biotechnol. 2001; 19:661-667. [PubMed: 11433279]

42. Alexandridis P, Holzwarthf JF, Hatton TA. Micellization of Poly(ethylene oxide)Poly(propyleneoxide)-Poly(ethylene oxide) triblock copolymers in aqueous solutions: Thermodynamics of copolymer association. Macromolecules. 1994; 27:2414-2425.

43. Tsui HW, Hsu YH, Wang JH, Chen LJ. Novel behavior of heat of micellization of Pluronics F68 and F88 in aqueous solutions. Langmuir. 2008; 24:13858-13862. [PubMed: 19053637]

44. Lee M, Celenza G, Boggess B, Blase J, Shi Q, Toth M, Bernardo MM, Wolter WR, Suckow MA, Hesek D, Noll BC, Fridman R, Mobashery S, Chang M. A potent gelatinase inhibitor with antitumor-invasive activity and its metabolic disposition. Chem Biol Drug Des. 2009; 73:189-202. [PubMed: 19207421]

45. Giambernardi TA, Grant GM, Taylor GP, Hay RJ, Maher VM, McCormick JJ, Klebe RJ. Overview of matrix metalloproteinase expression in cultured human cells. Matrix Biol. 1998; 16:483-496. [PubMed: 9550265]

46. Wanka G, Hoffmann H, Ulbricht W. Phase diagrams and aggregation behavior of poly (oxyethy 1ene)-poly (oxypropylene) -poly(oxyethylene) triblock copolymers in aqueous solutions. Macromolecules. 1994; 27:4145-4159. 


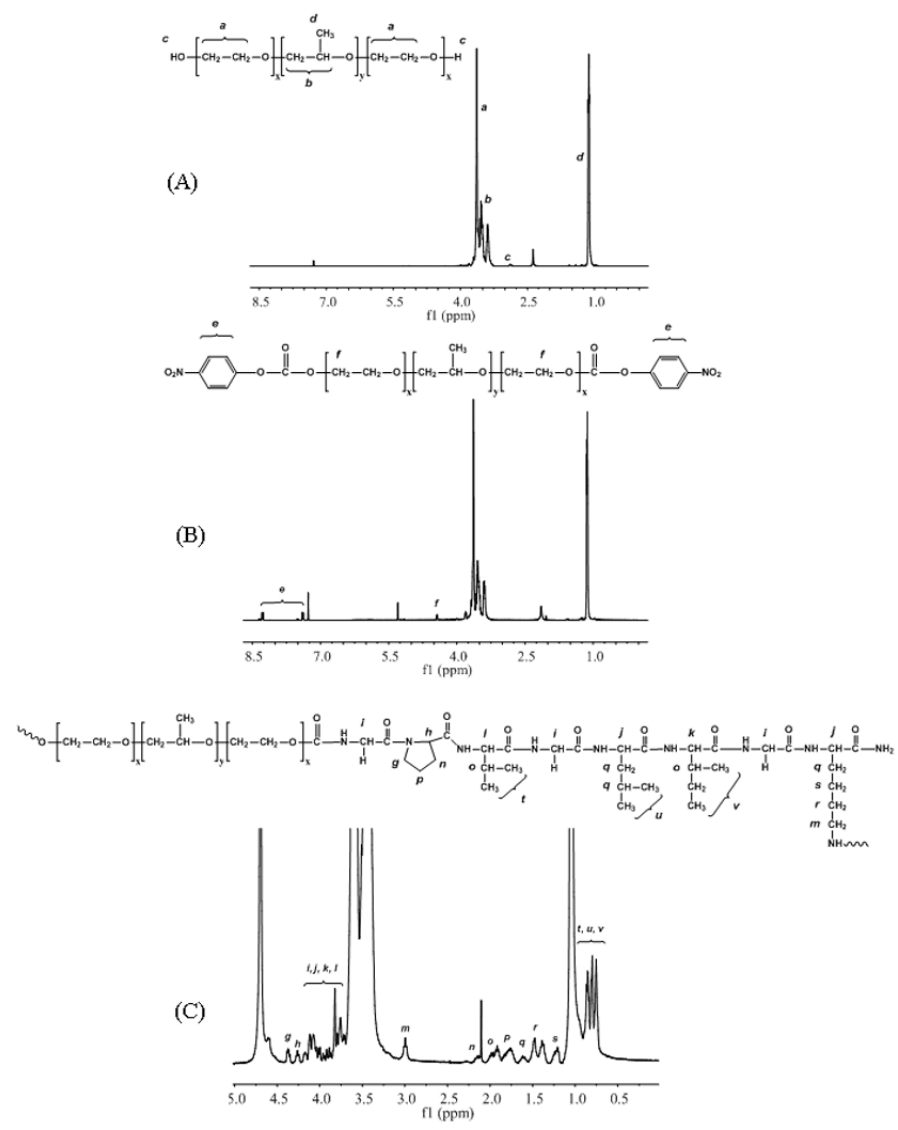

Figure 1.

${ }^{1} \mathrm{H}-\mathrm{NMR}$ spectra of (A) Pluronic ${ }^{\circledR}$ P104, (B) Activated Pluronic ${ }^{\circledR}$ P104 and (C) MMP-P104. $\mathrm{CDCl}_{3}$ was used to measure the NMR spectra of all polymers. 


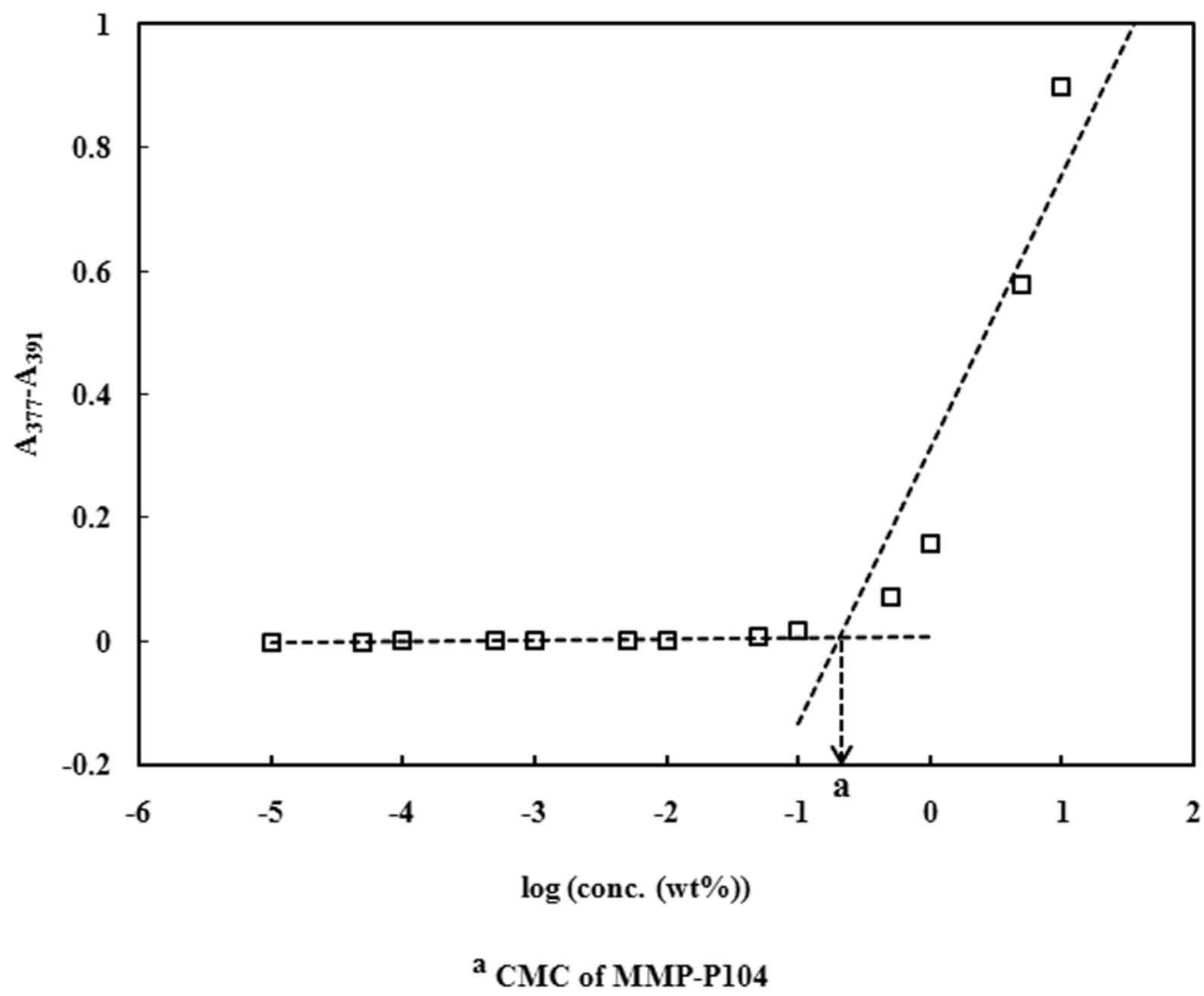

Figure 2.

CMC determination of MMP-P104 using a dye solubilization method. The CMC is defined as the point of intersection of two exponential lines. The CMC of MMP-P104 was found to be $0.208( \pm 0.012) \mathrm{wt} \%$. The CMC value represents the mean $\pm \mathrm{SD}$ of three experiments. 


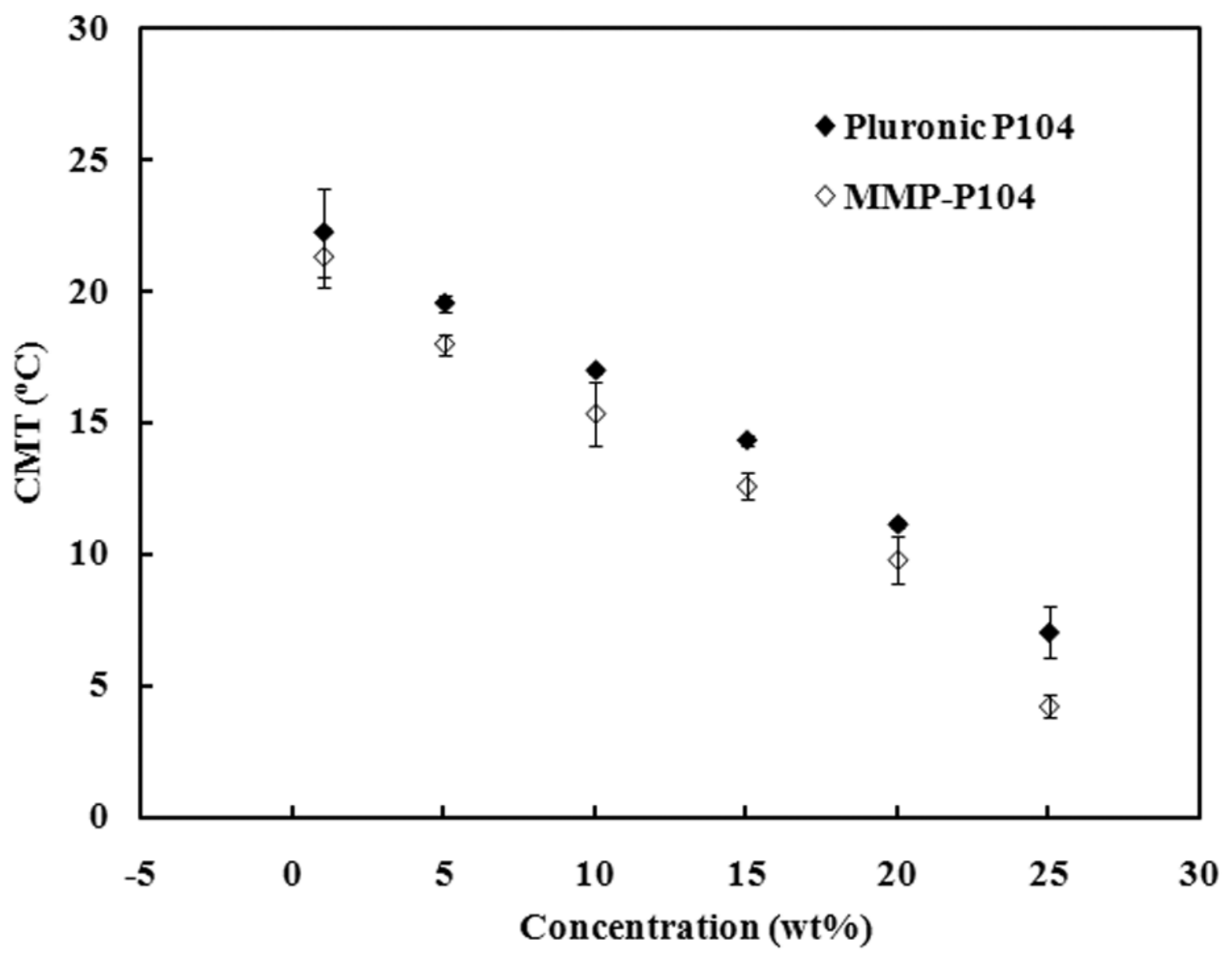

Figure 3.

Determination of CMT values of Pluronic ${ }^{\circledR}$ P104 and MMP-P104 solutions by DSC. The $\mathrm{CMT}$ value represents the mean $\pm \mathrm{SD}$ of three experiments. 


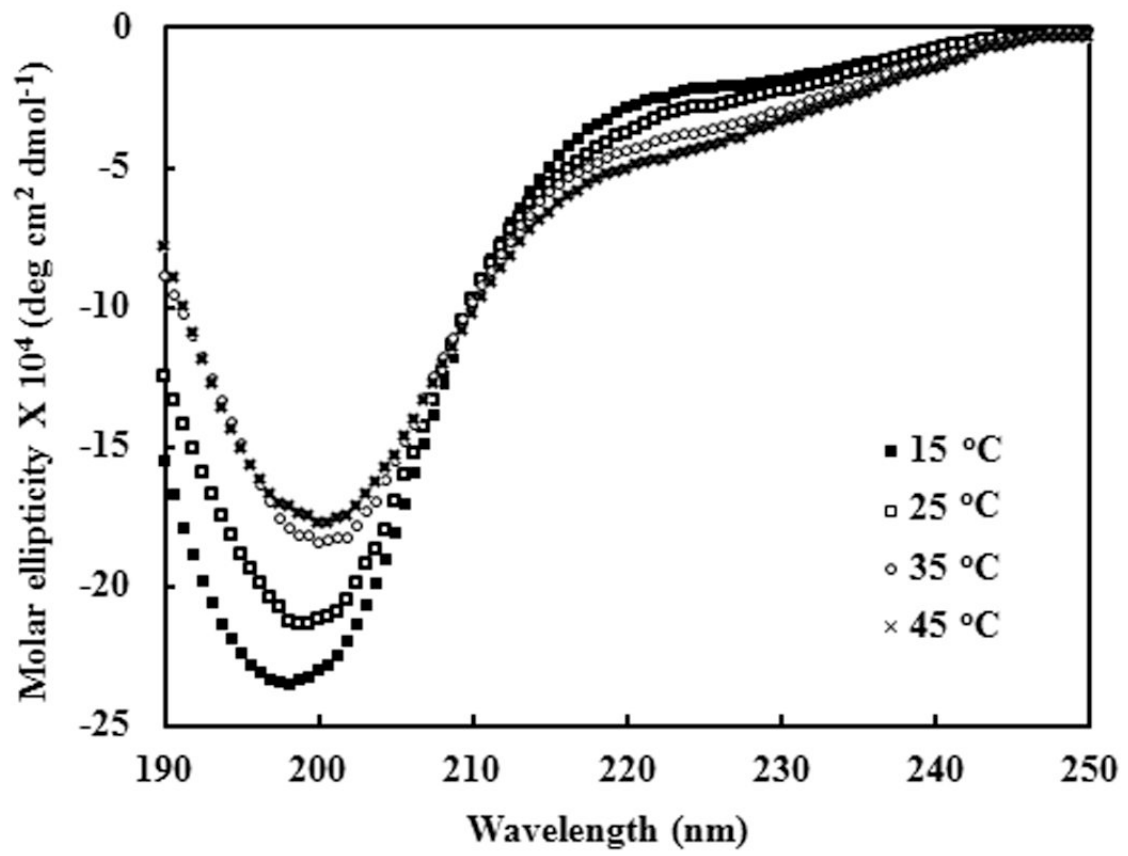

Figure 4.

CD spectra of MMP-P104 at different temperatures. Molar ellipticity was plotted on the vertical axis. All the solutions showed a negative band at $\sim 195 \mathrm{~nm}$ and a positive band at $\sim 215 \mathrm{~nm}$ 


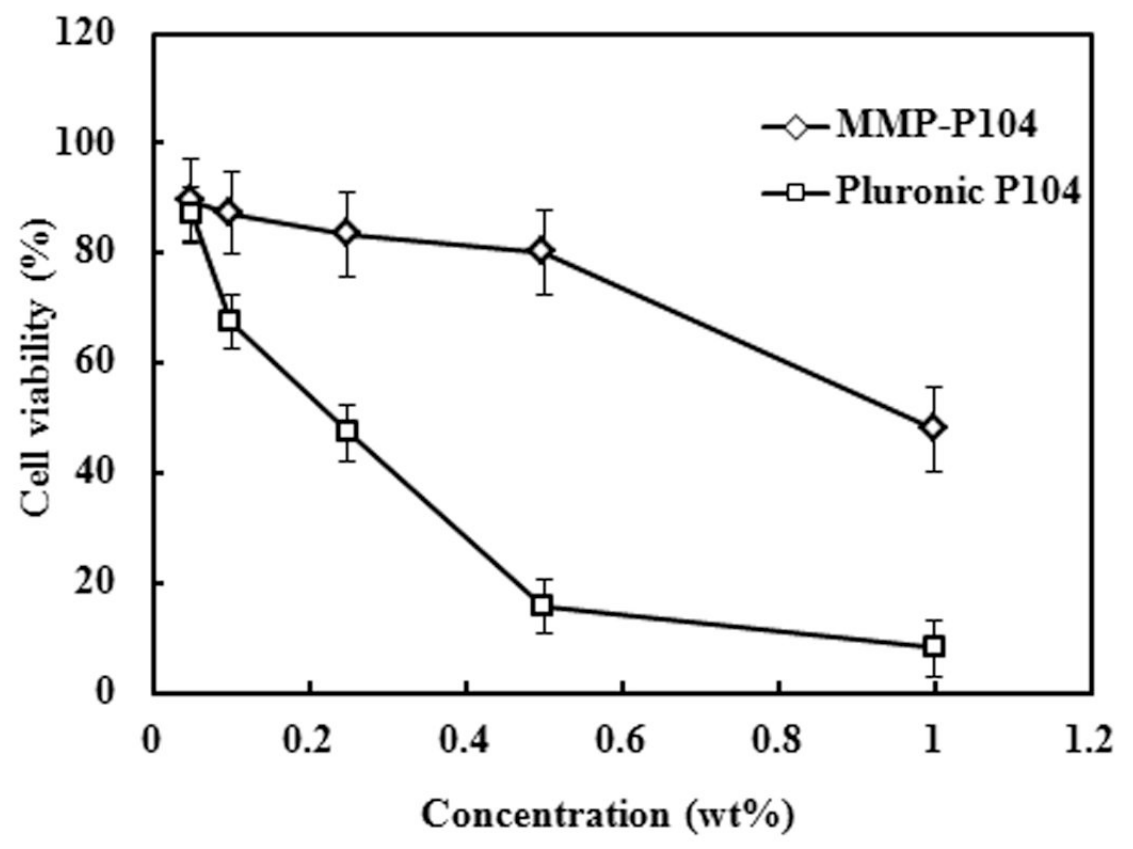

Figure 5.

Cell viability as a function of concentration was measured for Pluronic ${ }^{\circledR}$ P104 and MMPP104 on HT1080 cells. The results represent the mean \pm SD for $n=3$. 


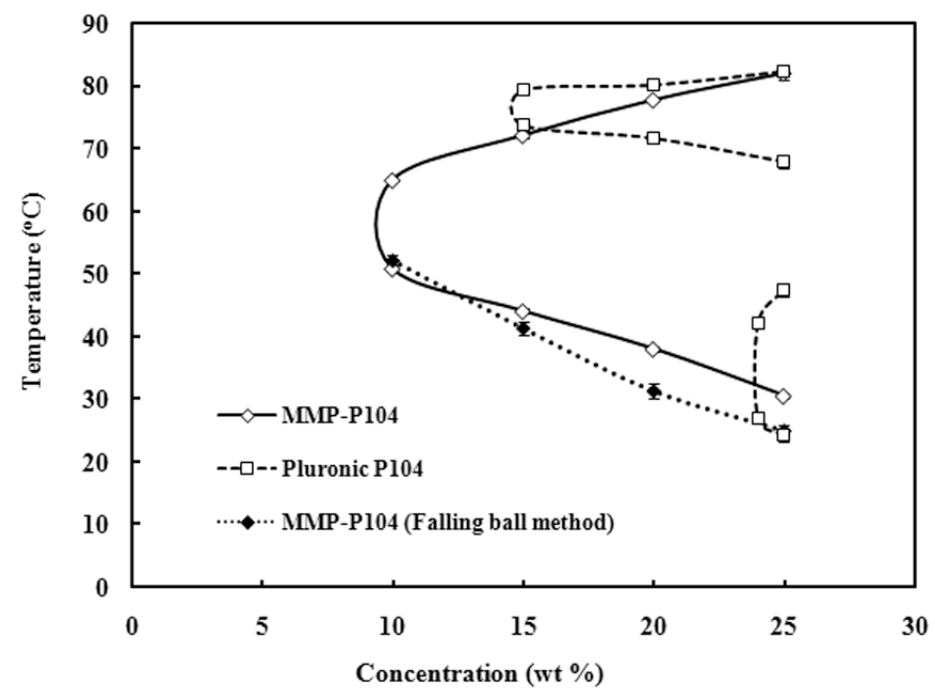

Figure 6.

Phase diagrams of Pluronic ${ }^{\circledR}$ P104 and MMP-P104 aqueous solutions constructed by both test tube inverting method and falling ball methods. The results represent mean $\pm \mathrm{SD}$ for $n=3$. 


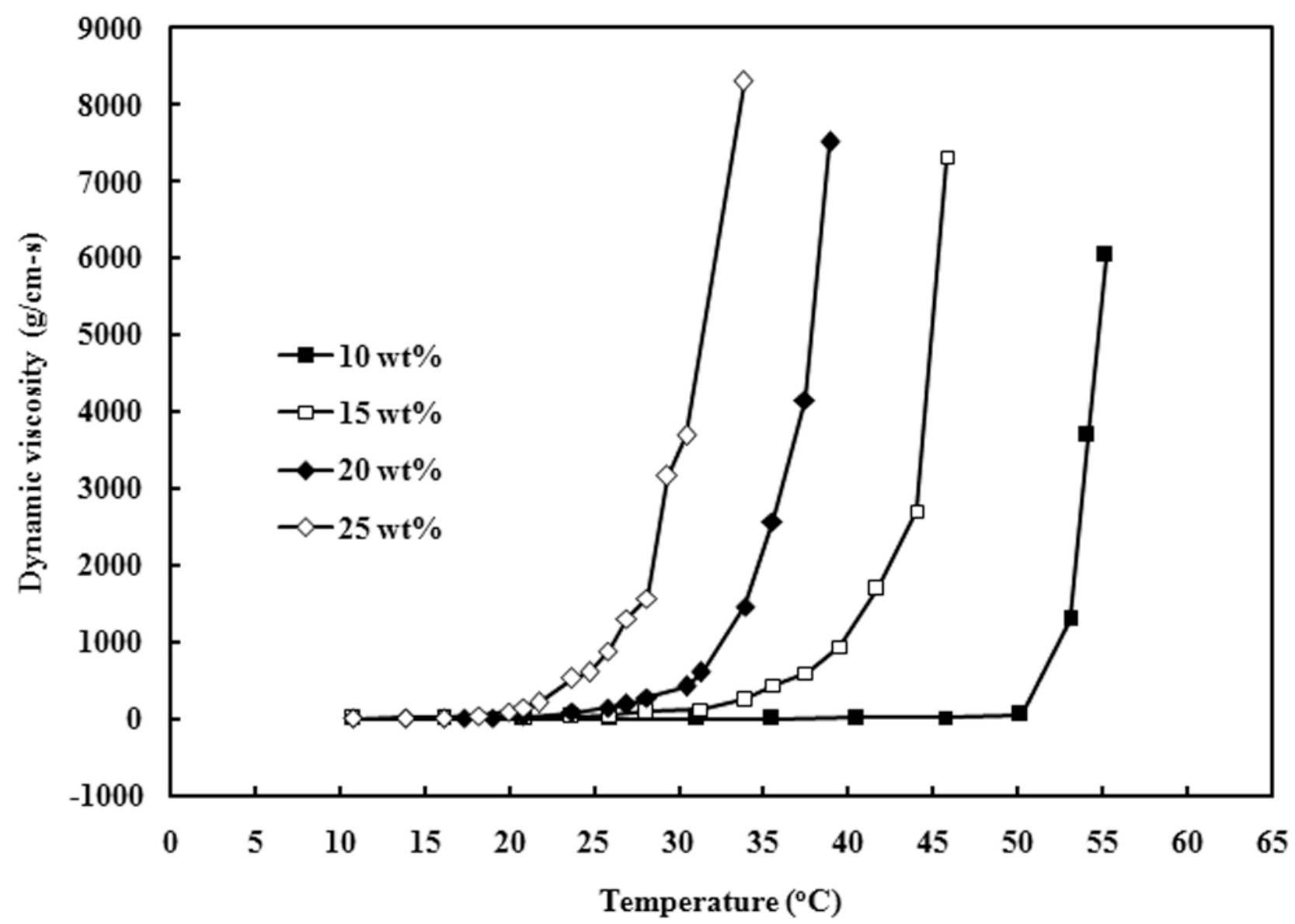

Figure 7.

Dynamic viscosity measurement of MMP-P104 solutions as a function of temperature. Dynamic viscosity was measured using falling ball method for different polymer concentrations. 
In absence of MMP-2

In presence of MMP-2
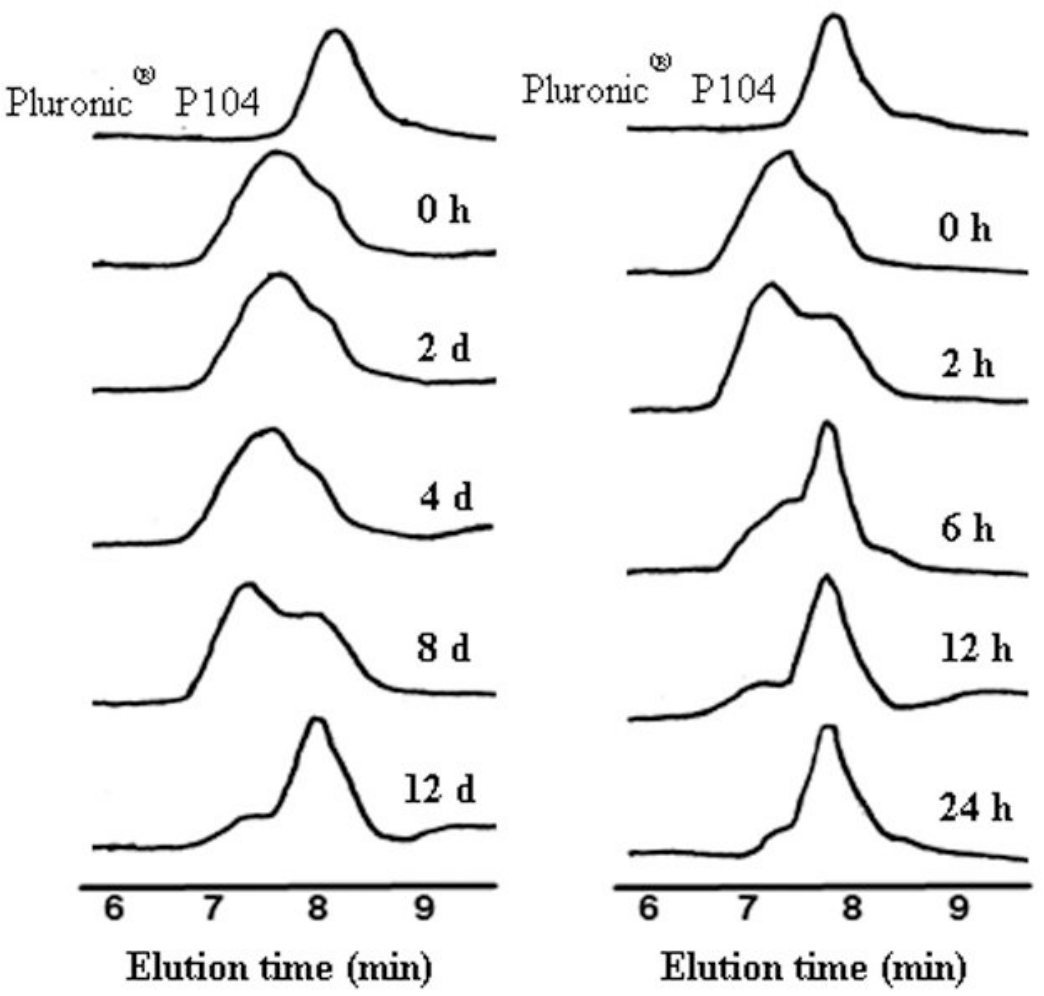

Figure 8.

GPC chromatographs showing MMP-P104 polymer degradation in presence or absence of MMP. The multiblock copolymers were degraded into lower molecular weight monomers. At 0 h, a small amount of unreacted Pluronic ${ }^{\circledR} \mathrm{P} 104$ was detected in the chromatographs of MMP-P104. 


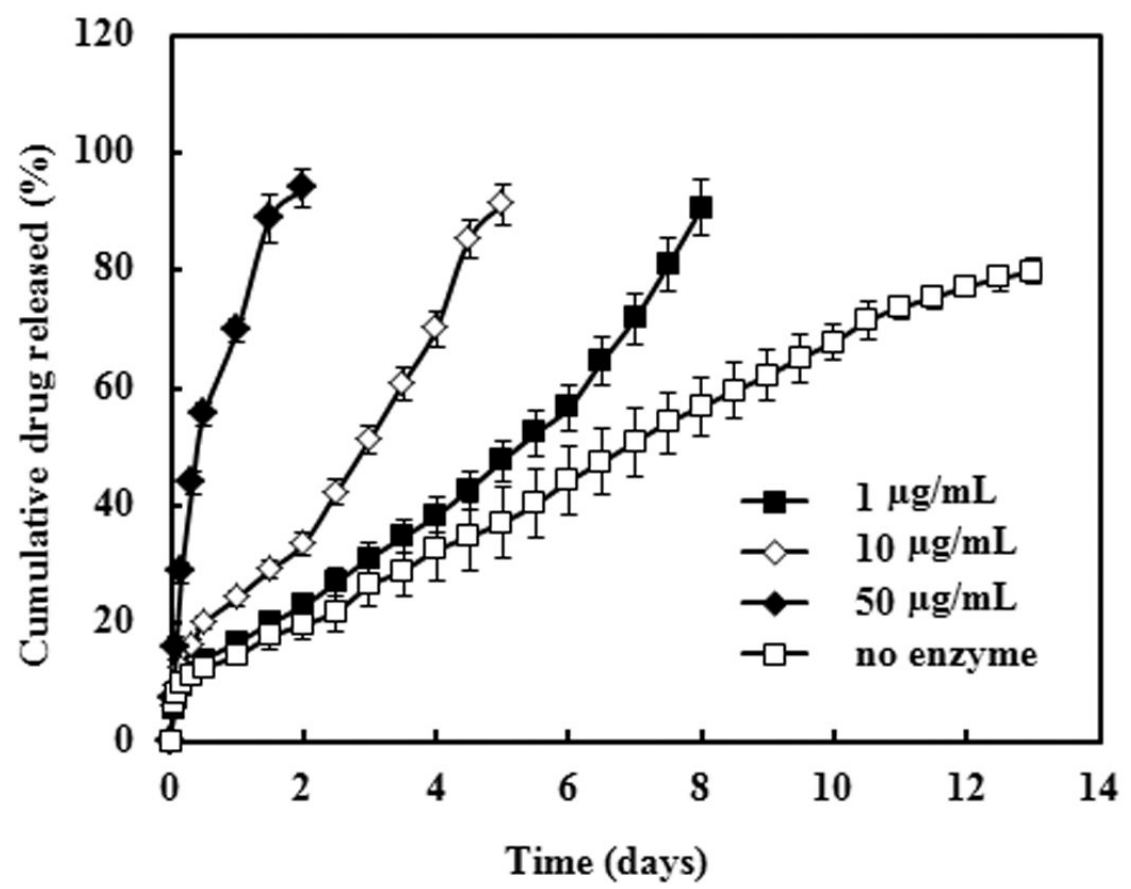

Figure 9.

PTX release at different MMP concentrations such as $0,1,10$ and $50 \mu \mathrm{g} / \mathrm{mL}$. The results represent mean $\pm \mathrm{SD}$ for $\mathrm{n}=3$. 


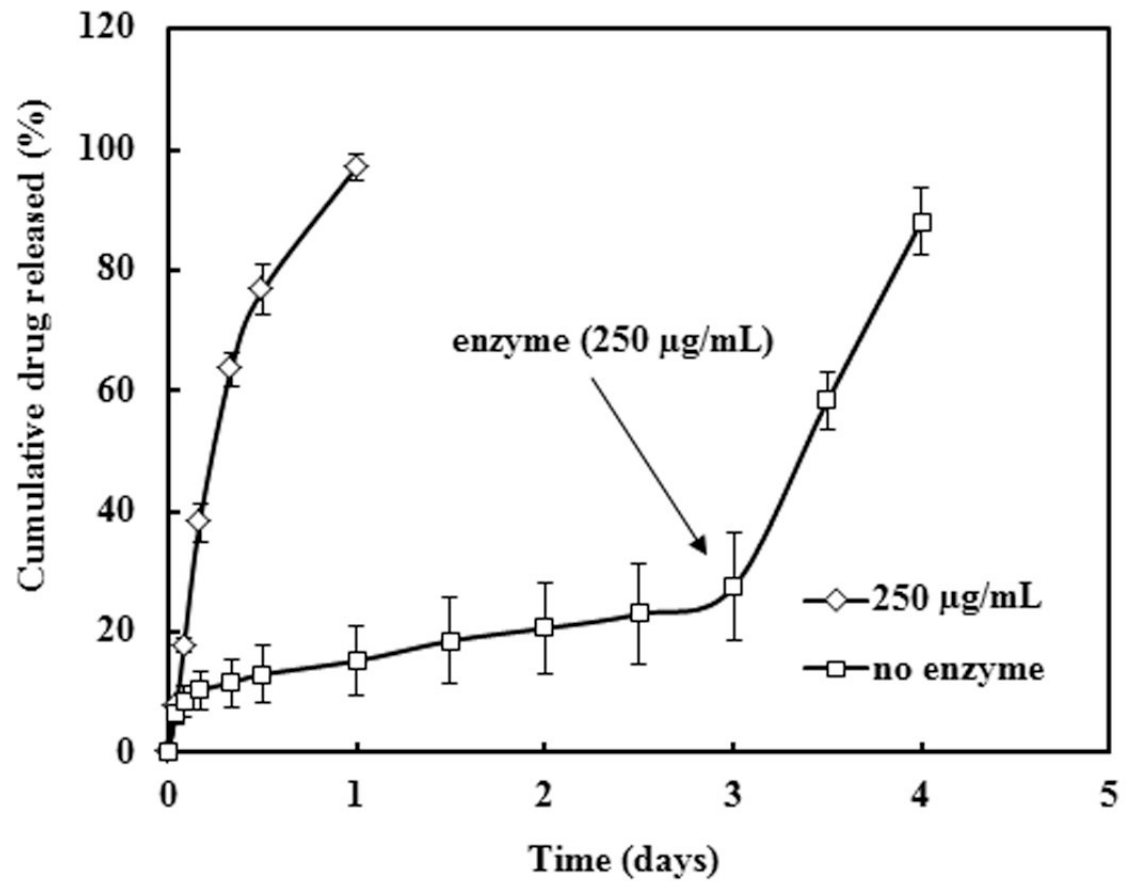

Figure 10.

PTX release from MMP-P104 thermogels with an alterating challenge of MMP free medium following MMP containing medium. The addition of MMP in the release medium at a concentration of $250 \mu \mathrm{g} / \mathrm{mL}$ triggered a fast drug release. The results represent mean $\pm \mathrm{SD}$ for $n=3$. 


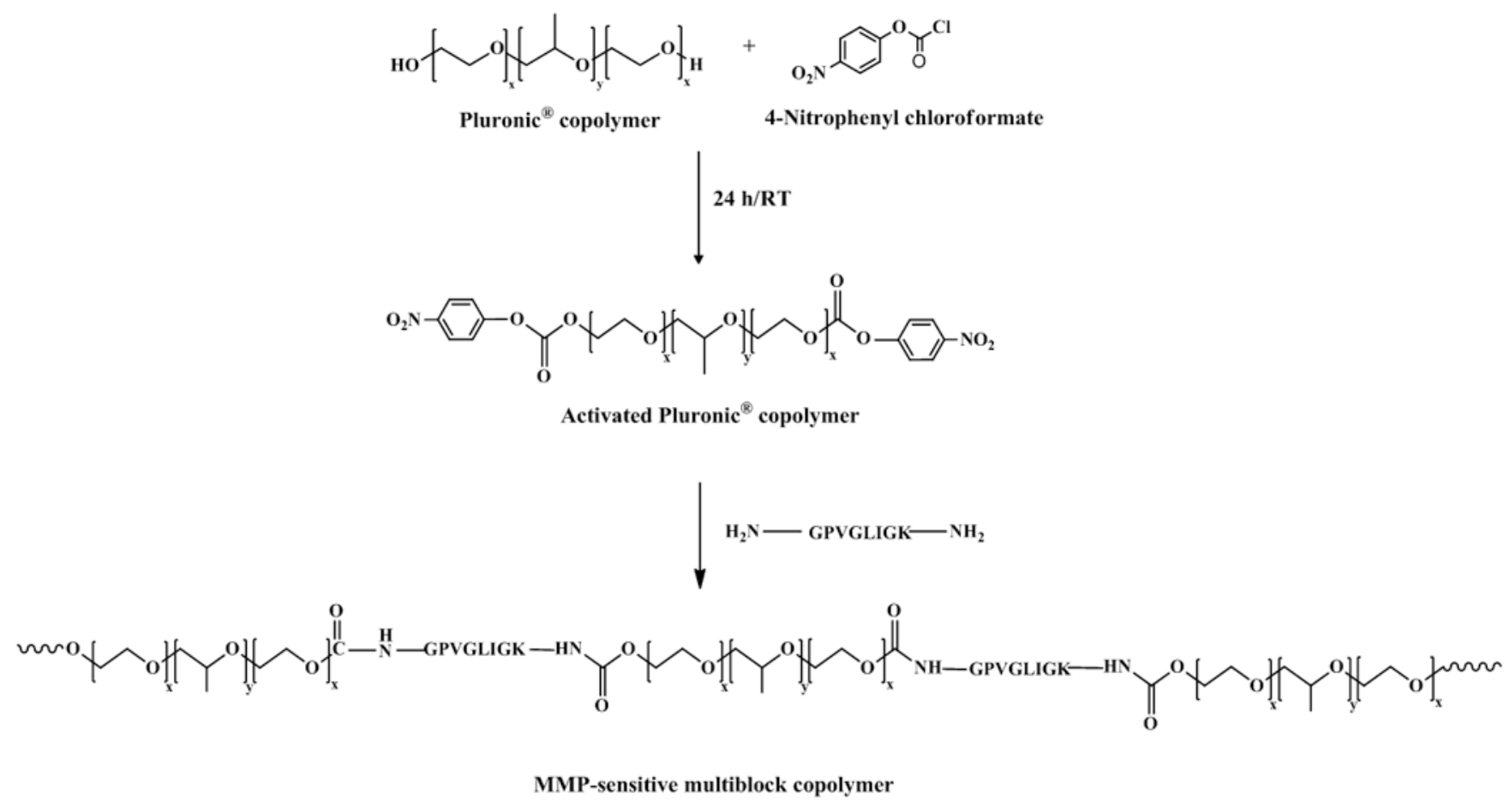

Scheme 1.

Two step reaction scheme showing the synthesis of MMP-sensitive multiblock copolymers from Pluronic ${ }^{\circledR}$ (P85 or P104) triblock copolymers. Pluronic ${ }^{\circledR}$ and NPC were reacted at room temperature for overnight to activate Pluronic ${ }^{\circledR}$. 


\section{Table 1}

Effect of different reaction conditions on the molecular weight of the final polymer. The $\mathrm{M}_{\mathrm{n}}$ values represent mean \pm SD for $n=3$.

\begin{tabular}{cccc}
\hline Polymer & Reaction conditions & $\mathbf{M}_{\mathbf{n}}(\mathbf{g} / \mathbf{m o l})^{\boldsymbol{a}}$ & $\mathbf{M}_{\mathbf{w}} / \mathbf{M}_{\mathbf{n}} \boldsymbol{b}$ \\
\hline 1 & RT (one day) & $17570( \pm 1060)$ & 1.34 \\
2 & RT (one day) $+50^{\circ} \mathrm{C}$ (one day) & $21120( \pm 960)$ & 1.47 \\
3 & RT (one day) $+50^{\circ} \mathrm{C}$ (two days) & $23270( \pm 1100)$ & 1.33 \\
\hline${ }^{a}$ Number average molecular weights determined by GPC \\
${ }^{5}$ Polydispersities based on GPC measurements
\end{tabular}




\section{Table 2}

Characterization of multiblock copolymers and triblock monomers. The $M_{n}$ and $T_{m}$ values represent mean \pm $\mathrm{SD}$ for $\mathrm{n}=3$.

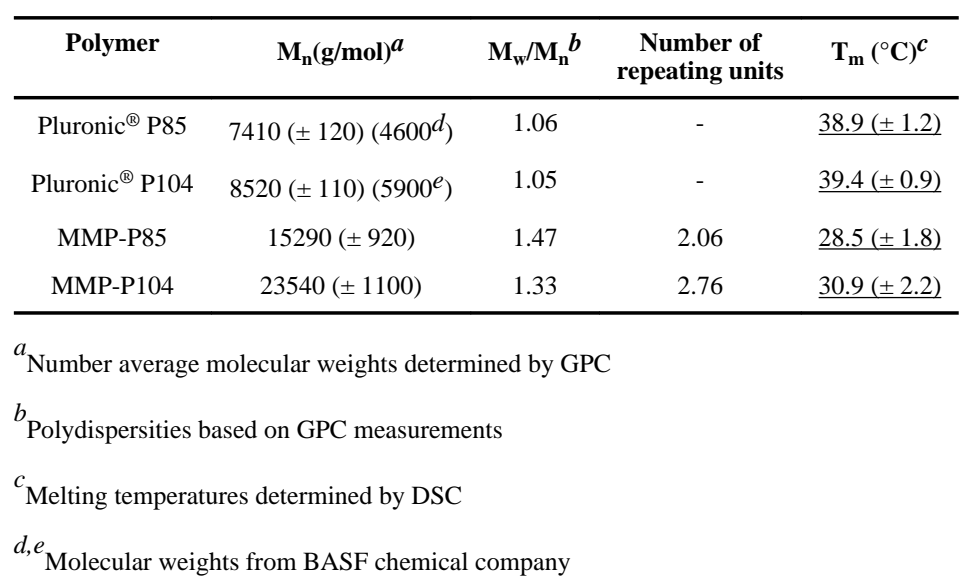

